\title{
A Cultural Political Economy of Financial Imaginaries: the (Re-)Making of 'BRIC' and the Case of China
}

Ngai-Ling Sum

\begin{abstract}
This article explores the role of economic/financial imaginaries (e.g., BRIC) from a cultural political economy (CPE) perspective. It is divided into four parts. Part one identifies some key questions from a CPE entry-point regarding the construction of economic imaginaries. Part two examines the role of (trans-)national forces in making and remaking the 'BRIC' (Brazil, Russia, India and China) as a 'growth' and 'hope' object over three overlapping stages. It notes that the national and transnational resonance of the BRIC imaginaries depends not only on developments in the financial and real economies but also on specific discourses, practices, and knowledge technologies. Part three examines how the 'BRIC' discourses are recontextualized in the Sinophone world as 'four golden brick countries' to signify 'strength' and 'greatest at last'. Part four investigates how China, as one of the 'golden bricks', was eager to showcase its strength following the 2007 financial crisis, which led to a fall in China's exports and rise in unemployment.. It promoted a vast stimulus package that has posed tremendous fiscal challenges, especially to its regional-local authorities, which increasingly rely on land as collateral for loans and source of revenue. This intensified land-based accumulation, inflating the 'property bubble' and stimulating land clearance/dispossession. In turn this has had very uneven effects on the 'subaltern south', illustrated here through impact on the aspirant middle class and migrant workers' children. Though some measures have been taken to dampen the property market, they have been rather limited and social unrest continues. Part five ends with some comments on the contribution of the cultural political economy approach in understanding the role of 'BRIC' as well as other new acronyms such as 'MINT' and 'MIST' as economic imaginaries.
\end{abstract}

Key Words: Cultural Political Economy, Financial Imaginaries, BRIC, China

\section{Introduction}

'BRIC' is the now well-known acronym for Brazil, Russia, India and China. It was coined by J im O'Neill, at the time Goldman Sachs' Chief Economist, when he watched the television broadcast of the 9/11 attacks on the World Trade Centre. He began to imagine a new way of thinking about 'growth' that could transcend national perspectives and look beyond the West. With the onset of the 2007 financial crisis, this imaginary gained fresh popularity and was reinvented through the concerted efforts of diverse national and transnational forces (for example, international investment banks, economic strategists, international organizations, think tanks, national governments, and business media corporations). In this light, the present chapter explores the development of discourses and practices of BRIC, considering them as economic and financial imaginaries from a cultural political economy perspective. Such imaginaries often involve a search for 'growth', hope' and 'strength' during specific economic conjunctures, especially periods of crisis.

Part one identifies some key questions from a CPE entry-point regarding the construction of economic imaginaries. Part two examines the role of (trans-)national forces in making and remaking the 'BRIC' as a 'growth' and 'hope' object over three overlapping stages. It notes that the national and transnational resonance of the BRIC imaginaries depends not only on developments in the financial and real economies but also on specific discourses, practices, and knowledge technologies. Part three examines how the 'BRIC' discourses are recontextualized in the Sinophone world as 'four 
golden brick countries' to signify 'strength' and 'greatest at last'. Part four investigates how China, as one of the 'golden bricks', was eager to showcase its strength following the 2007 financial crisis, which led to a fall in China's exports and rise in unemployment.. It promoted a vast stimulus package that has posed tremendous fiscal challenges, especially to its regional-local authorities, which increasingly rely on land as collateral for loans and source of revenue. This intensified land-based accumulation, inflating the 'property bubble' and stimulating land clearance/dispossession. In turn this has had very uneven effects on the 'subaltern south', illustrated here through impact on the aspirant middle class and migrant workers' children. Though some measures have been taken to dampen the property market, they have been rather limited and social unrest continues. Part five ends with some comments on the contribution of the cultural political economy approach in understanding the role of 'BRIC' as well as other new acronyms such as 'MINT' and 'MIST' as economic imaginaries.

\section{Towards a Cultural Political Economy of I magined Recoveries}

Cultural political economy (hereafter CPE) is a broad theoretical current that combines the 'cultural-linguistic turn' (namely, a concern with sense- and meaning-making) with critical political economy. It has been discussed at length in Chapter 2 and here I focus on its application to the emergence, recontextualization, circulation and sedimentation of the 'BRIC' imaginaries as objects of 'hope'/'strength' from 2001 until 2012. This has involved new discourses and what neo-Foucauldians call knowledging technologies (Dean 1999; Miller and Rose 2008).

A CPE approach recognizes not only the importance of discursive technologies but also the nature of the nodal discursive networks of individual and institutional actors (for example, international investment banks) in the (re-)making of social relations. It examines not only 'how' knowledge is constructed but also poses 'where', 'who', 'what' and 'why' questions. Specifically, it puts the following questions: (1) where does a particular economic imaginary (for example, BRIC) and its related discursive networks originate; (2) who are the actors that get involved in the discursive networks that construct and promote objects of 'hope'/'strength'; (3) what ideas (for example, BRIC consumer power) are selected and drawn upon to recontextualize and hybridize the referents of these objects; (4) how are these imaginaries normalized, translated and negotiated; (5) what knowledging technologies are involved in the constitution of subjectivities and identities; (6) how do these ideas enter the policy discourses and everyday practices of the financial and policy worlds; (7) how do they impact unevenly across different sites and scales (for example, the lives of subaltern groups); (8) how are they being negotiated and/or resisted in the rebuilding of social relations; and (9) why do these happen ${ }^{1}$ Answering these complex and difficult questions requires the investigator to examine the relations among discourse, power and structural materialities. The following analysis focuses on the BRIC imaginary and its appropriation and reconceptualization in Chine.

\section{The Construction of Hope/ Strength: Three-Stages in the Turn to 'BRI C'}

'BRIC' discourse is grounded in the notion of 'emerging markets', which was coined in 1981 by fund manager, Antoine van Agtmael of Emerging Markets Management. It maps some Third World' and post-socialist economies as sites of 'new growth opportunities' with 'high risks' but potentially high returns. 'BRIC' is a subset of the 'large emerging markets' and was identified as a high-growth investment group after 11 September 2001. The production of the 'BRIC' economic imaginaries has occurred in four overlapping stages, with others, perhaps, to come: (1) investor story, (2) investor-consumer story, and (3) investor-consumer-lender story. Each stage is related to nodal actors who are involved in the construction of 'hope'/'strength' via the use of knowledging instruments and technologies (see table 1) 
Table 1 The Production of 'Hope'/ 'Strength': Three Overlapping Stages in the Production of 'BRIC' Knowledge

\begin{tabular}{|c|c|c|c|}
\hline Stages & $\begin{array}{c}\text { Major } \\
\text { Actors/Institutions }\end{array}$ & $\begin{array}{l}\text { Major Discourses and } \\
\text { Knowledge Instruments }\end{array}$ & $\begin{array}{c}\text { Knowledging } \\
\text { Technology }\end{array}$ \\
\hline $\begin{array}{l}\text { Stage } 1 \text { 2001- } \\
\text { present } \\
\text { 'BRIC' as an } \\
\text { investor story }\end{array}$ & $\begin{array}{l}\text { International } \\
\text { investment banks } \\
\text { (e.g., Goldman Sachs) } \\
\text { Chief Economist (e.g., } \\
\text { Jim O’Neill) \& } \\
\text { colleagues; fund } \\
\text { managers, sales } \\
\text { teams, financial } \\
\text { journalists, rating } \\
\text { agency, etc. }\end{array}$ & $\begin{array}{l}\text { - } 2001 \text { Invented the } \\
\text { category in the report on } \\
\text { Building Better Global } \\
\text { Economic BRICs } \\
\text { - } 2003 \text { Research report on } \\
\text { 'Dreaming with BRICs: } \\
\text { The Path to 2050' } \\
\text { - Other reports, books, } \\
\text { webtours, indexes, etc. } \\
\text { (see table 2) }\end{array}$ & $\begin{array}{l}\text { Technology of } \\
\text { identification } \\
\text { Technology of } \\
\text { investability }\end{array}$ \\
\hline $\begin{array}{l}\text { Stage } 2 \text { 2004- } \\
\text { present } \\
\text { BRIC' as an } \\
\underline{\text { investor- }} \\
\underline{\text { consumer }} \\
\underline{\text { story }}\end{array}$ & $\begin{array}{l}\text { Economists, } \\
\text { investment } \\
\text { consultants, business } \\
\text { media (Bloomberg, } \\
\text { The Economist, CNN, } \\
\text { blogs, etc.), } \\
\text { international } \\
\text { organizations (e.g., } \\
\text { World Bank, IMF) }\end{array}$ & $\begin{array}{l}\text { Decoupling theses } \\
\text { - The trans-Atlantic } \\
\text { economies are in } \\
\text { recession due to the } \\
\text { subprime crisis and its } \\
\text { fallout. Other regions, } \\
\text { especially the BRIC, } \\
\text { continue to grow during } \\
\text { this downturn - strong } \\
\text { consumption } \\
\text { 'Decoupling 2.0' article } \\
\text { (The Economist) }\end{array}$ & $\begin{array}{l}\text { Technology of } \\
\text { identification }\end{array}$ \\
\hline $\begin{array}{l}\text { Stage } 3 \\
\text { Late 2008- } \\
\text { present } \\
\text { 'BRIC' as an } \\
\underline{\text { investor- }} \\
\underline{\text { consumer-lender }} \\
\text { story }\end{array}$ & $\begin{array}{l}\text { International } \\
\text { organizations (WB, } \\
\text { IMF, G20, BRIC } \\
\text { Summit, etc.), } \\
\text { national leaders, } \\
\text { foreign policy } \\
\text { analysts and mass } \\
\text { media }\end{array}$ & $\begin{array}{l}\text { - BRIC IMF Bond } \\
\text { Programme } \\
\text { - } \text { Buying IMF Special } \\
\text { Drawing Rights (e.g., } \\
\text { USD } 50 \text { bn by China in } \\
\text { 04/09/09) } \\
\text { - Shifting global economic } \\
\text { balance of power (e.g., } \\
\text { from G8 to G20 or even } \\
\text { G2) }\end{array}$ & $\begin{array}{l}\text { Technology of } \\
\text { agency }\end{array}$ \\
\hline
\end{tabular}

(Source: Author's own compilation) 


\section{First stage of the BRIC construction 2001- present: investor story}

Contrary to the fluid origin of most discourses, the BRIC idea has a clear starting point. It began with the imagination of the 'BRIC' quartet by Goldman Sachs' Chief Economist, J im O'Neill, following the attack on the World Trade Centre on 11 September 2001. He reckoned that further progress in globalization would need to go beyond Americanization and the northern-western world (Tett 2010). This diagnosis allowed O'Neill and his Goldman Sachs team to imagine new sources of growth based on identifying and bundling some useful 'non-western others' with high growth potentials. By 30 November 2001, these 'others' were presented as the 'BRIC' in Goldman Sachs Global Economic Paper No. 66, which was titled Building Better Global Economic Brics. Based on models of GDP growth rates until 2050, this economic quartet was constructed as the new object of 'hope', with 'each set to grow again by more than the G7' (2001: S.03). Whereas China and India were predicted to become dominant global suppliers of manufactured/technological goods and services, Brazil and Russia would grow as suppliers of energy and raw materials.

The creation of BRIC as a new 'growth' and 'hope' object for investors initially met with mixed responses. While Goldman Sachs' corporate clients, who were looking for new markets, were supportive of this construction, banks and investors were more sceptical at first because the BRICS were seen to be prone to 'shocks' from political upheavals and changing commodity prices. Nonetheless, O'Neill's team continued to supply their clients with 'hope' based on expected growth and financial returns. For example, Dreaming with BRICs: The Path to 2050 (2003), argued that:

The relative importance of the BRICS as an engine of new demand growth and spending power may shift more dramatically and quickly than expected. Higher growth in these economies could offset the impact of greying populations and slower growth in the advanced economies.

Higher growth may lead to higher returns and increased demand for capital. The weight of the BRICs in investment portfolios could rise sharply. Capital flows might move further in their favour, prompting major currency realignments...

(Wilson and Purushothaman 2003: 2)

On the discursive level, this construction of hope/strength was achieved through metaphors such as 'engine of growth' that could provide 'higher returns' and attract 'favourable capital flows'. The growth path was extrapolated up to 2050. By then, for example, China's RMB gross domestic product could be 30 per cent larger than US GDP, India's could be four times J apan's; and Brazil and Russia could be at least 50 per cent bigger than the UK economy. References to economic attributes like size and rates of growth can be seen, in neo-Foucauldian terms, as a technology of identification in which the BRIC are singled out, made knowable, and visibilized as the largest, high growth and potentially lucrative 'emerging economies'. This identification technology, once deployed, was circulated by the Goldman team and other actors such as fund managers and financial sales teams. With the continuing consolidation of neoliberal globalization and China's entry into the WTO since 2001, more and more corporations and financial organizations were looking for new markets and profitable investment sites beyond the core advanced economies. New discursive networks, which included corporate executives, investment bankers, fund managers, and so on, began to appropriate and disseminate the BRIC imaginary as their own object of investment and strategic actions. Moreover, as Tett (2010) records, after the 2003 paper, Goldman economists entered 'briclife' with growing interest from leading clients in this new object of hope and speculative returns. 
Goldman sustained this interest by churning out more knowledge products. Between 2001 and 2010, it created 20 such products, ranging from reports, new forecasts, a book, videos, and webtours (in different languages) to keep 'briclife' going ${ }^{2}$ (see table 2). This Goldman story was occasionally challenged by other economists and investment consultants, who asked why some emerging economies were excluded (for example, South Korea and Turkey) and others included (for example, Russia and Brazil). New acronyms were put forward (for example, BRICK and CRIB) to negotiate its meanings and appeals.

Table 2 Major BRIC Knowledge Products Constructed by Goldman Sachs Team

\begin{tabular}{|c|c|c|}
\hline $\begin{array}{l}\text { Name of the } \\
\text { Knowledge } \\
\text { Products }\end{array}$ & $\begin{array}{c}\text { Nature of } \\
\text { Product } \\
\text { (Year/ Month) }\end{array}$ & Ways of Constructing Hope and Strength \\
\hline $\begin{array}{l}\text { Building Better } \\
\text { Global Economic } \\
\text { BRICS }\end{array}$ & $\begin{array}{l}\text { Report } \\
\text { November } 2001\end{array}$ & $\begin{array}{l}\text { - Invented the BRIC category and forecast combined GDP } \\
\text { growth rate of } 12 \% \text { in the next } 10 \text { years }\end{array}$ \\
\hline $\begin{array}{l}\text { Dreaming with } \\
\text { BRICS: The Path to } \\
2050\end{array}$ & $\begin{array}{l}\text { Report } \\
\text { October } 2003\end{array}$ & $\begin{array}{l}\text { - Mapping out BRIC's GDP growth until } 2050 \\
\text { - Postulating BRIC economies could be larger than G6 in } \\
40 \text { years' time }\end{array}$ \\
\hline $\begin{array}{l}\text { How Solid are the } \\
\text { BRICS? }\end{array}$ & $\begin{array}{l}\text { Forecast } \\
\text { December } 2005\end{array}$ & $\begin{array}{l}\text { Updating the } 2003 \text { forecast } \\
\text { Arguing that BRIC grow more strongly than projection }\end{array}$ \\
\hline $\begin{array}{l}\text { Web Tour: The } \\
\text { BRICS Dream (in } \\
\text { English, Arabic, } \\
\text { Chinese and } \\
\text { Japanese) }\end{array}$ & $\begin{array}{l}\text { Webtours } \\
\text { May } 2006\end{array}$ & $\begin{array}{l}\text { - A video on the BRIC } \\
\text { - Dreaming about BRIC and the changing world after 9/11 } \\
\text { - Contending China would overtake the USA in } 2050 \\
\text { - Arguing Growth of the middle classes in BRIC and major } \\
\text { consumers of cars and energies }\end{array}$ \\
\hline $\begin{array}{l}\text { India's } \\
\text { urbanization: } \\
\text { Emerging } \\
\text { opportunities }\end{array}$ & $\begin{array}{l}\text { Report } \\
\text { July } 2007\end{array}$ & $\begin{array}{l}\text { - Framing boom in city life } \\
\text { - Identifying investment opportunities in urban } \\
\text { infrastructure and fast accumulation of financial assets }\end{array}$ \\
\hline$B R / C S$ and Beyond & $\begin{array}{l}\text { Book } \\
\text { November } 2007\end{array}$ & $\begin{array}{l}\text { - Updating the } 2001 \text { report } \\
\text { - Postulating increase in value of BRIC's equity markets } \\
\text { - Moving beyond BRIC to other emerging economies } \\
\text { (e.g., } \mathrm{N}-11 \text { ) }\end{array}$ \\
\hline
\end{tabular}




\begin{tabular}{|c|c|c|}
\hline $\begin{array}{l}\text { Interview with Jim } \\
\text { O'Neill }\end{array}$ & $\begin{array}{l}\text { Video } \\
\text { February } 2008\end{array}$ & $\begin{array}{l}\text { - Maintaining BRIC's share of global GDP as } 15 \% \\
\text { - Advising individual BRIC countries (e.g., India needs } \\
\text { more FDI) } \\
\text { - Arguing for the sustainability of BRIC } \\
\text { - Increasing international role of these countries }\end{array}$ \\
\hline $\begin{array}{l}\text { Building the World: } \\
\text { Mapping } \\
\text { Infrastructure } \\
\text { Demand }\end{array}$ & $\begin{array}{l}\text { Report } \\
\text { April } 2008\end{array}$ & $\begin{array}{l}\text { - Identifying increase demand for infrastructure } \\
\text { - Arguing China will be the source of one-half to three- } \\
\text { quarter of incremental demand } \\
\text { - Intensifying pressure on commodity markets }\end{array}$ \\
\hline $\begin{array}{l}\text { Ten Things for } \\
\text { India to Achieve its } \\
2050 \text { Potential }\end{array}$ & $\begin{array}{l}\text { Repor } \\
\text { J une } 2008\end{array}$ & $\begin{array}{l}\text { - Advising on improvement of governance and the need } \\
\text { to control inflation } \\
\text { - Promoting the liberalization of financial market } \\
\text { - Supporting improvement for agricultural productivity }\end{array}$ \\
\hline $\begin{array}{l}\text { BRICS Lead the } \\
\text { Global Recovery }\end{array}$ & $\begin{array}{l}\text { Report } \\
\text { May, } 2009\end{array}$ & $\begin{array}{l}\text { - Arguing BRIC can help to led the stabilization of the } \\
\text { world economy } \\
\text { - Promoting BRIC is one of the driving forces in the } \\
\text { export-driven recovery }\end{array}$ \\
\hline $\begin{array}{l}\text { The BRICS as } \\
\text { Drivers of Global } \\
\text { Consumption }\end{array}$ & $\begin{array}{l}\text { Report } \\
\text { August } 2009\end{array}$ & $\begin{array}{l}\text { - Arguing G3 countries face slow and difficult recovery } \\
\text { - Maintaining that BRIC can contribute to global domestic } \\
\text { demand through higher consumption }\end{array}$ \\
\hline $\begin{array}{l}\text { The BRICS Nifty } \\
\text { 50: The EM \& DM } \\
\text { winners }\end{array}$ & $\begin{array}{l}\text { Report and stock } \\
\text { baskets } \\
\text { November } 2009\end{array}$ & $\begin{array}{l}\text { - Stating good consumption and infrastructural demand } \\
\text { from BRIC } \\
\text { - Identifying two BRIC Nifty } 50 \text { baskets to help investors } \\
\text { to access the BRIC market }\end{array}$ \\
\hline $\begin{array}{l}\text { BRICS at 8: Strong } \\
\text { through the Crisis, } \\
\text { Outpacing } \\
\text { forecasts }\end{array}$ & $\begin{array}{l}\text { Video } \\
\text { March } 2010\end{array}$ & $\begin{array}{l}\text { - BRIC weathered the global crisis remarkably well } \\
\text { - On pace to equal the G7 in size by } 2032\end{array}$ \\
\hline $\begin{array}{l}\text { The Growth Map: } \\
\text { Economic } \\
\text { Opportunities of } \\
\text { BRICS and Beyond }\end{array}$ & Book 2012 & $\begin{array}{l}\text { - A sole-authored book by O'Neill that reviews the } \\
\text { economic opportunities of BRICS and beyond }\end{array}$ \\
\hline
\end{tabular}

(Source: Author's own compilation based on materials from Goldman Sachs' Idea Website on BRIC) 
Nonetheless, despite these challenges, with one wag later suggesting that BRIC stood for 'bloody ridiculous investment concept' and another proposing CEMENT to describe 'countries in emerging markets excluded by new terminology', the Goldman construction of the BRICs as objects of 'hope'/'strength' continued to circulate amongst economic strategists, investment consultants, and sales teams and attract continuing media attention. Its resonance derived not only from the projection of strength of the individual BRIC group members but also from the purported complementarity and coherence of BRIC as an asset/investment form. Major international banks such as HSBC and other investment banks/hedge funds were bundling stocks/shares/bonds and inventing funds marketed under the BRIC brand. Starting initially with a few funds and index funds, the market has since grown in terms of offers and funds invested (for details, see Sum and J essop 2013). Great emphasis was placed on their attractiveness as investments because of the spread of risks, asset allocation and portfolio management, prospective profits, and the involvement of legendary stock pickers and fund management by gurus. In neo-Foucauldian terms, this discourse and technology of investability: (1) constructs strength, profitability and confidence of these funds and narrated them as asset choices; (2) directs investor subjects to put their money in these economies; and (3) normalizes BRIC as investment sites.

Table 3 BRI C I nvestment Funds and their Construction of Strength and Profitability

\begin{tabular}{|l|l|l|l|}
\hline $\begin{array}{l}\text { Recommended } \\
\text { Fund }\end{array}$ & Reasons for Choice & $\begin{array}{l}\text { Breakdown of } \\
\text { ETF* by Country }\end{array}$ & $\begin{array}{l}\text { Top } 10 \text { Components } \\
\text { Consist of Giant Firms }\end{array}$ \\
\hline $\begin{array}{l}\text { iShares MSCI } \\
\text { BRIC Index Fund }\end{array}$ & $\begin{array}{l}\text { A portfolio of about } 175 \\
\text { stocks from BRIC } \\
\text { countries. Despite a gain } \\
\text { in excess of 40\% year-to- } \\
\text { date, the fund is still down } \\
\text { over 30\% over the past } \\
\text { 52 weeks, so valuations } \\
\text { are still not back to pre- } \\
\text { crisis levels }\end{array}$ & $\begin{array}{l}\text { Kong: 42\%, Brazil: } \\
\text { and Russia: 13\% }\end{array}$ & $\begin{array}{l}\text { China Mobile, Gazprom, } \\
\text { Reliance Industry, } \\
\text { Petrobras, Vale, Itaú } \\
\text { Unibanco, HDFC Bank, } \\
\text { China Life Insurance, } \\
\text { Lukoil, and Industrial \& } \\
\text { Commercial Bank of China }\end{array}$ \\
\hline $\begin{array}{l}\text { Templeton } \\
\text { Emerging Markets } \\
\text { Fund }\end{array}$ & $\begin{array}{l}\text { The fund is managed by } \\
\text { emerging market guru, } \\
\text { Mark Mobius. Mobius has } \\
\text { been with the Templeton } \\
\text { since 1987 and has blazed } \\
\text { the trail for emerging } \\
\text { markets investors }\end{array}$ & $\begin{array}{l}\text { Kong: 23\%, Brazil: } \\
\text { 23\%, India: 10\%, } \\
\text { Russia: 9\%, } \\
\text { Thailand: 8\%, } \\
\text { Turkey and South } \\
\text { Korea: 7\% each }\end{array}$ & $\begin{array}{l}\text { Akbank, Denway Motors, } \\
\text { Itau Unibanco, Sesa Goa, } \\
\text { Banco Bradesco, Aluminum } \\
\text { Corp of China and SK } \\
\text { Energy }\end{array}$ \\
\hline
\end{tabular}

(Source: Adapted from Invest U 2009 to fit a tabular form) 
Armed with these investment products, financial sales teams and other intermediaries marketed them to potential clients, contacting them through advertisements, glossy brochures, financial journalism, phone-calls, home visits, and so on. Knowledging technology and related investment practices of this kind normalize BRIC as a good source of investment. Coupled with the general search for new investment sites, the inflow of portfolio equity funds to BRIC increased by almost twelvefold between 2002 and 2007. As for the share of BRIC investment inflow compared with its counterpart in development countries, BRIC's share was about two-third of total inflow between 2003 and 2007 (see table 4). Within the BRIC group, China was the biggest gainer in 2006 and India in 2007. With the onset of the financial crisis, the credit crunch led to the sharp slowdown of inflow to the BRIC in 2008 with China as the exception of a positive inflow of USD 3.7 billion.

Table 4 Net I nflows of Portfolio Equity to the BRI C Economies 2002-2008

(\$ billion)

\begin{tabular}{l|c|c|c|c|c|c|c} 
Country & $\mathbf{2 0 0 2}$ & $\mathbf{2 0 0 3}$ & $\mathbf{2 0 0 4}$ & $\mathbf{2 0 0 5}$ & $\mathbf{2 0 0 6}$ & $\mathbf{2 0 0 7}$ & $\mathbf{2 0 0 8}$ \\
\hline China & 2.2 & 7.7 & 10.9 & 20.3 & 42.9 & 18.5 & 3.7 \\
India & 1.0 & 8.2 & 9.0 & 12.1 & 9.5 & 35.0 & -15.0 \\
Brazil & 2.0 & 3.0 & 2.1 & 6.5 & 7.7 & 26.2 & -7.6 \\
Russia & 2.6 & 0.4 & 0.2 & -0.2 & 6.1 & 18.7 & -15.0 \\
BRIC & $\mathbf{7 . 8}$ & $\mathbf{1 9 . 3}$ & $\mathbf{2 2 . 2}$ & $\mathbf{3 8 . 7}$ & $\mathbf{6 6 . 2}$ & $\mathbf{9 8 . 4}$ & $\mathbf{- 3 3 . 9}$ \\
Developing & $\mathbf{5 . 5}$ & $\mathbf{2 4 . 1}$ & $\mathbf{4 0 . 4}$ & $\mathbf{6 8 . 9}$ & $\mathbf{1 0 4 . 8}$ & $\mathbf{1 3 5 . 4}$ & $\mathbf{- 5 7 . 1}$ \\
Countries & $\mathbf{4}$ & &
\end{tabular}

(Source: Adapted from World Bank, Global Development Finance 2008 and 2010)

\section{Second stage of the BRI C construction 2004-present: investor-consumer story}

The BRIC as investor story was extended to include a consumption dimension from mid-2004. This began again with a report from the Goldman team, which published a report on The BR/CS and Global Markets: Crude, Cars and Capital (2004). It identified an 'emerging middle class' in these economies, which would lead to increasing demand for commodities, consumer durables and capital services. This BRIC 'dream' was echoed by economic strategists such as Clyde Prestowitz, whose book, Three Billion New Capitalists. projected that, by 2020, '... the annual increase in dollar spending by the BRIC will be twice that of the G6 (2005: 227).

This BRIC-as-consumer story gained more resonance with the growing visibility of the financial crisis that started from the 2007 collapse in the US sub-prime housing market. The long chains of financial bankruptcy of financial houses, bailouts and credit crunch led the policy communities to look for new signs of 'hope' and possible objects of recovery. Among other objects (for example, the Green New Deal), the BRIC story was re-articulated to include a consumption dimension (see table 1). Thus stage two attributed a new locomotive role to the BRIC on the grounds that their consumer-led demand would defer recession and create recovery opportunities for recession-ridden advanced economies.

This narrative was enthusiastically circulated/negotiated by economists, business media (including Bloomberg, Newsweek, The Wall Street Journal, and CNM and international organizations such as the IMF under the rubric of the 'decoupling thesis'. This asserts that the BRIC economies can still expand on the basis of their own investment and consumption, despite recession in the advanced economies. Jim O'Neill was reported in Bloomberg as saying that 'the BRIC consumer is going to 
rescue the world' (Marinis 2008) and 'since October 2007, the Chinese shopper alone has been contributing more to global GDP growth than the American consumer' (Mellor and Lim 2008). As in stage one, the technology of identification was deployed and BRIC was reinvented to become such 'decoupled' object with autonomous consumption power that could operate as 'saviours' of global recession.

This story was popularized by discursive networks of top investment advisors and fund managers through business, mass and Internet media (Shinnick 2008; Lordabett.com 2009). For example, Peter Schiff, President of Euro-Pacific Capital Inc, was one prominent proponent of this thesis and his position was echoed in many YouTube videos, blogs, articles, and news items. A typical supportive statement was found in his book, Little Book of Bull Moves in Bear Markets, in which he argued:

I'm rather fond of the word decoupling, in fact, because it fits two of my favorite analogies. The first is that America is no longer the engine of economic growth but the caboose. [The second] When China divorces us, the Chinese will keep 100\% of their property and their factories, use their products themselves, and enjoy a dramatically improved lifestyle (Schiff 2008:41).

Nonetheless the 'decoupling thesis' is also negotiated in different ways. First, some financial analysts, economists and international/regional organizations, such as the World Bank and Asia Development Bank, were more cautious. They pointed to a contraction of trade rather than decoupling. For example, in April 2008, citing reduced exports, the World Bank lowered its growth forecast for China to 6.5 per cent. Second, a different kind of caution was expressed in June 2008, when the IMF released a study called Convergence and Decoupling. This argued that decoupling could co-exist with integration. The globalization that has occurred since 1985 has stimulated greater trade and financial integration and this, in turn, has led to the tighter coupling of business cycles among countries with similar levels of per capita income. But there was also historical evidence that some (groups of) countries have decoupled from the broader global economy at various stages of their development. Third, a different concern was expressed by the UK-based foreign affairs think tank, Chatham House, in the wake of the collapse of Merrill Lynch and Lehman Brothers in September 2008. In one briefing paper, Synchronized Dive into Recession, a Chatham House author argued:

Will a severe OECD recession engulf the rest of the world? Up to mid-2008, the emerging markets remained strong - 'decoupling' did work. Now the crisis has deepened, no region will remain immune to shock waves (Rossi 2008).

In spite (or perhaps because) of these different views and the ambiguity of the '(de-) coupling' arguments, the thesis was still circulated. Indeed, Jim O'Neill himself reinforced it Newsweek in March 2009:

Who said decoupling was dead? The decoupling idea is that, because the BRICS rely increasingly on domestic demand, they can continue to boom even if their most important export market, the United States, slows dramatically. The idea came into disrepute last fall, when the U.S. market collapse started to spread to the BRICS, but there's now lots of evidence that decoupling is alive and well (O'Neill 2009).

This claim was echoed by the Economist when it presented 'Decoupling $2.0^{\prime}$ ' in its issue of 21 May 2009. This new version interpreted decoupling as 'a narrower phenomenon, confined to a few of the biggest, and least indebted, emerging economies' such as China, India and Brazil. These economies had strong domestic markets and prudent macroeconomic policies and were also growing 
trade among themselves. In an interview on 'Decoupling is Happening for Real', Michael Buchanan, Goldman Sachs' Asia-Pacific Economist in Hong Kong, explained:

For the last couple of months, data have revealed a growing divergence between western economies and those in much of Asia, notably China and India. ....

One reason for this divergence is that the effects of the financial crisis hit Asia much later. While the American economy began slumping in 2007, Asian economies were doing well until the collapse of Lehman Brothers in September. What followed was a rush of stimulus measures - rate cuts and government spending programs. In Asia's case, these came soon after things soured for the region; in the United States, they came much later though on a much bigger scale.

In addition, developing Asian economies were in pretty good financial shape when the crisis struck. The last major crisis to hit the region - the financial turmoil of 1997-98 forced governments in Asia to introduce overhauls that ultimately left them with lower debt levels, more resilient banking and regulatory systems and often large foreign exchange reserves (Buchanan 2009).

This creative argument reinterpreted the BRIC-decoupling thesis by narrowing the focus to two BRIC members: China and, to a lesser extent, India. In highlighting the 'new decoupling' thesis, this latest step construed them as 'useful others' with large foreign exchange reserves, buoyant fiscal positions and financial stimulus packages. In November 2009, the World Bank raised its 2010 economic forecast for China's GDP growth to 8.4 per cent. These economies offer 'hope' in terms of their good investment markets, robust consumption from their rising middle classes and relative large stimulus packages (see table 5). This narrowing of BRIC to China and India was reinforced within the policy circuit by Roger Scher who wrote for the Foreign Policy Blogs Network. He questioned the strength of Russia and whether the growth of China and India needs to seen as 'From BRIC to BIC... or Even IC?? Others constructed the term 'BriC' to highlight the position of China (see next section).

\section{Third stage of the BRIC construction: investor-consumer-lender story}

This new version of the decoupling thesis survived into stage three, which began in late 2008 (see table 1). As the crisis in the developed countries deepened and the search for 'hope' or objects of recovery continued, more attention was paid to the geo-political significance of the BRIC quartet. At this stage, a greater role in the construction of 'hope' was played by policy makers, international organizations, think tanks, foreign policy analysts, and so on. An interesting example of this trend occurred as the UK Prime Minister, Gordon Brown, was coordinating an IMF rescue package for the global economy in October 2008 and called for the support of countries with large reserves. He stated:

China ... has very substantial reserves. There are a number of countries that actually can do quite a lot in the immediate future to make sure that the international community has sufficient resources to support countries that get themselves into difficulties (cited in Sanderson 2008).

This plea was reiterated as Brown prepared for the G20 meeting in London in April 2009, when China was expected to contribute USD 40 billion to the rescue package. Accompanying these specific policy initiatives, foreign policy rhetoric emphasized the emergence of a 'multipolar world order' and 'comprehensive interdependence' among countries (Renate 2009). These new geopolitical imaginaries became more credible when Russia held the first BRIC Leaders' Summit in Yekaterinburg in J une 2009 and Brazil, China, India and South Africa $^{3}$ hosted the second, third and fourth summits 
in April 2010, April 2011, March 2012 and March 2013. These summits operated (partly) as arenas for the BRIC(s) leaders to perform and confirm their collective identity as well as to envisage their future (for example, the establishment of the BRIC Development Bank) despite of their differences.

Thus, in reaction to Brown's 2009 call for them to support the IMF rescue package, the BRIC governments agreed to contribute towards a more diversified international monetary system. Influenced by Stiglitz's UN Commission on Reforms of the International and Monetary Systems and the discussions around the UN Conference on the Global Financial \& Economic Crisis, it advocated Special Drawing Rights' (SDRs) as the new 'global currency' that could increase liquidity. The IMF would issue SDR-denominated bonds that the BRIC economies could purchase for their reserves. This new approach was backed at the G20 Summit in April 2009, when the IMF managing director, Dominique Strauss-Kahn, announced the issuance of USD 250 million SDR-denominated bonds. The IMF Executive Board confirmed this on $1 \mathrm{~J}$ uly 2009, China pledged to buy USD 50 billion, and Russia, Brazil and India would each gradually purchase USD 10 billion.

In contrast to conventional IMF loan facilities, this form of financing involved new kinds of lender and governance relations with implications for the BRIC economies. As lenders to the IMF, the strength of the BRIC quartet was reconfirmed symbolically via: (1) the developed economies' recognition that they should be part of the solution to the crisis by subscribing to these SDRdenominated bonds; (2) their general unwillingness to commit funds on a long-term basis until the IMF re-allocated the country quotes; and (3) their specific demand for an increase in their voting shares within the IMF governance structure from 5 to 7 per cent of the total. ${ }^{4}$ Despite these signs of 'hope'/'strength', some observers commented that the new SDR bonds would only absorb a small proportion of the BRIC's foreign reserves and, therefore, doubted that the SDR system would ever challenge the role of the dollar (Kelly 2009).

This (negotiated) amalgam of 'BRIC' discourses and practices (and their continued reworking and re-articulation over three overlapping stages) has helped to sediment and naturalize BRIC as a complex object of 'hope'/'strength'. It deferred the recession by offering investment opportunities for frustrated investors, consumer demand that can facilitate recovery and growth, and reserves that can finance international lending. Given these alleged strengths, the BRIC economies are deemed to have graduated from being 'emerging markets' to an 'emerging global power'. This discursive shift illustrates what neo-Foucauldians call a technology of agency (Cruikshank 1999) that is based on the coexistence of participation and control in the international arena. On the one hand, there is the encouragement of the BRIC to participate as 'we' in the new so-called multipolar world order. Using the power shift from G8 to G20 as an example; BRIC's increasing roles in the G20 allow for their participation on one hand; and on the other hand, it also steers the manner of their engagement, for example, as engines of consumption, lenders to the IMF, and so forth. Such participation, coordination and steering of the BRIC economies in arenas such as the G20 enables the emergence of a broader 'discussion forum' to address crisis-related issues as well as producing directives to international organizations (for example, the IMF). One effect is that the BRIC economies are drawn into discussions and actions around crisis-management that facilitate the rebuilding and negotiation of the future neoliberal agendas (for example, the dollar-yuan exchange policy, BRIC as consumers, and the dollar's hegemonic role).

\section{BRI C-ing of China and I ts 2008 Stimulus Package}

The transition of the BRIC imaginary of 'hope'/strength through these stages was not a smooth process. The BRIC identity and its boundary is constantly (re-)negotiated by a mix of (trans- 
)national actors. On the transnational level, there were global market strategists and economists who asked why some emerging economies were excluded (for example, South Korea) and others included (Russia). Some foreign policy analysts question the coherence of the quartet, leading one to use 'BRIC-à-Brac' to convey their diverse and toothless nature (Drezner 2009). ${ }^{5}$ More prosaically, others warned of the potential 'BRIC bubble' by arguing that, even if their GDP continued to expand, this might not translate into higher stock market returns for investors (Tasker 2010; Evans-Pritchard 2011).

In the Sinophone world, the term 'BRIC' is translated as 'bricks' and has been recontextualized, initially in Taiwan and then more widely, as 'the four golden brick countries' (金磚四 國). The 'golden bricks' imaginary has been embraced by the financial and official communities within China as a symbol of 'strength' and sign of 'greatness-at-last'. This reinforces China's long-standing construction of 'national strength' under a one-party authoritarian regime. There were plenty of printed headlines in its official newspaper, The People's Daily, that adopted BRIC-related discourses such as 'Shining, golden "BR/C"' (6 September 2006) and 'BR/C set to build golden brick' (16 J une 2009). This 'golden' metaphor helps to signify the strength and pride of the Chinese nation, especially after its long history of foreign invasion and national humiliation. More specifically, this claim to strength expressed quantitatively in terms of a 'shinning BRIC' that can 'protect 8\% GDP growth rate'.

With the onset of the 2007 North Atlantic Financial Crisis, there was a sharp fall in Chinese exports and growing unemployment. The Chinese central government pro-actively used the crisis for profiling purpose both nationally and internationally. It re-iterated its 'protection of $8 \%$ GDP growth rate' to project strength as well as a justification for putting together a vast stimulus package of RMB 4 trillion (USD 586 bn) from November 2008. Concurrently, the US Federal Reserve sought to stimulate its domestic economy by quantitative easing in late November 2008. It 'printed money' to buy USD 600 billion mortgage-backed securities with the effects of increasing lending activities both at home and abroad.

While the Federal Reserve deployed quantitative easing to support banks deemed to big to fail, China stimulated its economy via loan-based programmes that have affected national-local social relations unevenly. In particular, its use of fiscal and monetary stimulus has intensified the fiscal imbalances between the central-local relationships. It was narrated officially as providing support for ten major industrial sectors (for example, steel, shipbuilding, electronics, and petrochemicals), building infrastructural projects (for example, high speed rail, electric grid), boosting consumer spending, developing the rural economy, and encouraging education and housing (for details, see Tong and Zhang 2009). However, based on fiscal practice since the late 1990s, this vast sum was financed by around one-third from central government funding; the rest was expected to come from regional-local governments, governmental ministries, and state-owned enterprises (SOEs) (see table 5). To enable these loans, the central government introduced policies such as loosening of credit policies, and abolishing credit ceiling for commercial banks. 
Table 5 The Central-Local Government's Share of the Stimulus Package and Sources of Finance in China 2008-2010

\begin{tabular}{|c|c|c|c|}
\hline $\begin{array}{c}\text { Level of } \\
\text { Government }\end{array}$ & $\begin{array}{c}\text { Amount (in } \\
\text { Trillion RMB) }\end{array}$ & $\begin{array}{c}\text { Percentage of } \\
\text { Total }\end{array}$ & Major Sources of Finance \\
\hline $\begin{array}{l}\text { Central } \\
\text { government }\end{array}$ & 1.2 & 29.5 & $\begin{array}{l}\text { - Direct grants } \\
\text { - Interest-rate subsidies }\end{array}$ \\
\hline $\begin{array}{l}\text { Regional-local } \\
\text { governments }\end{array}$ & 2.8 & 70.5 & 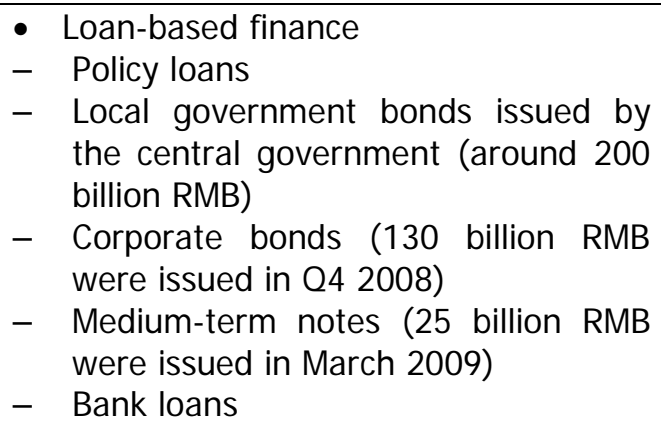 \\
\hline
\end{tabular}

(Source: Window of China 2009; Naughton 2009)

\section{China's stimulus package, 'property bubble' and the 'subaltern' South}

When these stimulus measures were communicated to the ministries and local governments, they were eager to seize this opportunity and get their pet projects (for example, high-speed trains, industrial upgrading projects) approved (Naughton 2009). Given the central-local fiscal arrangements since the 1990s, local governments are required to provide matching funds. They find this hard because (1) they are expected to channel 60 per cent of their revenue to Beijing; (2) the economic downturn reduced revenue from business taxes; and (3) they have no formal mandate to borrow money. This inevitably resulted in a funding gap. Thus a 2009 National Audit Office survey reported that local governments in 18 provinces were failing to provide the expected level 'matching funds', with the poorest performing province sending only 48 per cent of the amount due (Xi et al., 2009).

In planning terms, this shortfall can be filled by financial resources coming from a mix of local government bonds issued by the central government, corporate bonds, medium-term notes and bank loans (see table 5). However, as China's bond market is not well-developed, local governments seek their own sources of finance. This chapter concentrates on the intensification of the use of land as a means to generate income. This is possible as China's land leasehold market was formally established in the late 1970s under Deng Xiao-Ping. Urban land is state-owned but the separation of ownership and land-use rights mean that public and private actors can shape its disposition and utilization. Urban land-use rights could be leased for fixed periods (for example, 70 years for residential housing) at a fee and land-right leases are tradable by auctions (Hsing 2010: 36). This development encourages local officials to convert rural land, which still belongs to rural 'collectives', into urban land by compensating (at least in principle) village communities.

With these socio-economic changes, local governments can commodify land in two main ways: as an instrument for leveraging loans and source of revenue. First, local governments have accumulated land, licences and equity investments. However, such assets cannot be translated into cash because the Budget Law prohibits these authorities from raising funds directly. Local governments therefore set up related investment companies to raise loans from state-owned banks 
(for example, Bank of China, China Construction Bank). Land-use rights are used as collateral for these loans. With the easy availability of credit and the close relationship between local governments and state-owned banks, local government debt rose five times between 2008 and 2009 from 1 trillion RMB (USD 146 billion) to an estimate of 5 trillion RMB (USD 730 billion) by the end of 2009 (Zhang 2010). Concurrently, Bank of China and China Construction Bank reported profit rose of 26 and 15 percent respectively for 2009 (Business Weekly 2010).

Second, land-right leases and auctions are used to generate government revenue and stimulate economic growth. These rights are sold to private and state-owned developers (for example, China Poly Group, China Resource Group and China Merchant Group) for property projects. In 2009, the Ministry of Land and Resources reported local governments generated 1.6 trillion RMB (USD 233 billion), which was a 60 per cent increase compared with 2008. Of these land sale revenues in 2009, 84 per cent came from property development (China Daily 2010). In this regard, real estate development provides two benefits: first, it is a major source of fiscal revenues for local governments and this provides strong incentives for them to support these endeavors; and, second, state-owned and private property developers (and their partners in local governments) can earn high profit from selling housing units, especially when easy credits is available from state-controlled banks.

This land-based development and its perceived benefits have strengthened the emerging social attitude that property ownership is a source of economic security, hedge against inflation, social status, family safety net and personal pride. The business press, ordinary media, and peer pressures help to reinforce these views in everyday life. Given the limited outlets to invest savings, continuously rising property values over the last decade suggested that real estate offers higher returns; indeed, low interest rates and the absence of a national property tax allowed speculative property to be purchased and held relatively cheaply. Thus real estate came increasingly to be seen as an object of investment, ownership and/or speculation. Such private economic-investment calculation is articulated with the central government's focus on high growth rates, dependency of local governments upon land/real estate for revenue, the drive of real-estate developers for profit, and the inflow of funds from quantitative easing in the US. All these factors contributed towards real estate inflation as well as fears of a 'property bubble'. According to Colliers International, residential prices in 70 large- and medium-sized cities across China rose in 2009, with 50 to 60 per cent increases in Beijing and Shanghai. Such increases reduce housing affordability with the conventionally calculated income-to-price ratio in Beijing at 1 to 22 (Smith 2010; Powell 2010; FlorCruz 2009). This ratio means that housing prices for a standard property are 22 times the average annual income of families.

This inflationary rise has added a political dimension to the housing question. This was acknowledged by the Premier Wen Jiabao when he remarked on 27 February 2010 that 'property prices have risen too fast' and this 'wild horse' has to be tamed. Central government leaders have been taken measures to dampen the market (for example, tightening of credit, raising deposits for purchase of new land to 50 per cent; arranging for the exit from this sector of state-owned developers whose core business is not property, imposing a property tax on residential housing, and so on.). However, such measures have merely encouraged banks to find other ways to increase their credit (for example, selling off loans to state-owned trusts and asset-management companies and turning loans into investment products and selling them to private investors). These practices are supported by those with vested interests in the property boom, such as jobs and perks for officials, income and growth statistics for ministries and local governments, profit/investment for state-owned banks and related investment vehicles as well as state-owned/private property developers, and, of course, benefits to property owners (on the real estate coalition, see Sum 2011). 
Such apparent advantages to (inter-)national-regional-local elites come at a price. Overinvestment in real estate and projects destabilizes the economy and has a weakens the socioeconomic positions of ordinary citizens and the 'subaltern south'. While many issues and sites could be discussed (for example, land seizures, peasant protests, nail houses, and so on.), two social issues will be briefly explored here: the affordability of housing and plight of migrant workers in rural towns.

First, the rise of property prices is based on and reinforces the view that property ownership represents a profitable investment and personal security. This underpins the stimulus-loan-property boom and its socio-economic base. Rising property prices, wealth accumulation and regular land auctions co-exist with social unrest related to resettlement compensation, land clearance, affordability of housing/schooling, conditions of migrant workers, inflationary pressures, and petty and major corruption. These socio-economic issues have been reflected and popularized in TV sitcoms such as Dwelling Narrowness (Snail House) about struggles to acquire property and corruption among officials and have also supplied material for countless newspaper columns, policy speeches, and appeals for action. A major theme in this regard is the plight of white-collar workers who have become virtual 'house slaves' (房奴). These are the white-collar employees who, in the midst of soaring property prices propelled by an easy-credit and over-investment stimulus package, slave to save the deposit for flats and to pay their mortgage, and then struggle to balance domestic budgets. It seems as if it is not these workers who own their flats or houses, but their houses and flats that own them and dictate their working lives and family relationship.

Second, uneven development is reflected in the plight of the migrant workers in rural towns on the periphery of cities. These workers constitute a significant part of the reserve army of labour and the bedrock of the Chinese export-led growth. While they have no opportunity to become "house slaves', they (and their children) risk displacement by the same property boom dynamic. For this accelerates land clearance in rural towns to make way for real estate projects and therefore displaces workers and raises their rents. Such cases are so rampant that there is rising social unrest related to land appropriation, under-compensation for land/property seizure, corruption, rising prices, and so on. In October 2010, a blogger called 'Blood Map' used Google Map to chart the distribution of sites where there have been land conflicts, use of violence against residents, and people's resistance to illegal land grab and property demolitions in China. ${ }^{6}$

Land appropriation and clearance also affect migrant workers especially their children. Migrant families have no hukou (long-term residency) ${ }^{7}$ in urban areas and they go to privately-run schools set up in slums in these rural towns. These schools provide inexpensive schooling. Urban clearance means that this kind of affordable education may vanish due to school closures. Some schools are now categorized as 'illegal' (and hence receive no compensation for closure) by the local authorities. These 'schools' and authorities are locked in compensation battles as well as faced with the fate of closing down ( Li 2010). Some children are locked out from schools, some are rehoused in make-shift schools, and some are sent back to home villages. In the last case, social issues arise around 'left-behind children' living with grandparents (or other relatives).

There are currently some 20 million 'left-behind children' in China. This also raises more general issues concerning the 'rights of migrant workers' and a hukou system that creates secondclass citizens. In response to these challenges, 13 newspapers throughout China issued a joint call for the abolition of the 'outdated' hukou system ${ }^{8}$ on 2 March 2010, but this was soon silenced in a matter of days. The authorities continuously talk of reorienting policies and putting more resources into the social agenda (for example, housing, education, and health care). However, as the stimulus package is largely land-led, the injection of funds into healthcare and social housing tends to grow more slowly than economic expansion, especially where the latter is fuelled by easy credit, land sales and real 
estate development. These are tied very closely to the vested interests of regional-local governments, the property-owning elite, state-owned banks, state-owned/private property developers, infrastructure-related departments and organizations, and so on. There have been recent calls to tighten credit by suspending home loans to buyers purchasing third housing unit; rebalance the economy towards greater financial liberalization, reform central-local fiscal relationship and embark on social development. These measures are likely to be counteracted by different groups with vested interests in a particular mode of accumulation. These struggles will continue and tensions are expressed on different levels. On the social level, there is the rise in social unrest (for example, Wukan peasant riot) and the demand for the return of land. On the economic level, the central government's push for rebalancing towards financial liberalization has stimulated resistance from state-owned and export-oriented sectors.

\section{Concluding Remarks: I mplications for Turkey}

This chapter uses a CPE approach to examine the discursive-material bases of the development of the BRIC imaginary since 2001. Taking the 'cultural-linguistic turn' seriously in the study of political economy, it has identified three overlapping stages in the construction of the BRIC economies as (trans-)national object of 'growth'/'hope'/'strength'. These stages were not arbitrary but related to major new material conjunctures - the 9/11 attack on the World Trade Centre and the financial crisis that has been unfolding since 2007. A CPE approach would highlight the importance of this material conjuncture and to examine how diverse actors experiment with discourses and practices that would orient their interpretations and actions in changed structural circumstances. Some of these discourses (such as the 'decoupling thesis') have been negotiated, selected, deepened, sedimented and naturalized as efforts to manage the security and financial crises continued. In addition, a CPE approach would also examine how: a) these processes have been mediated by discursive networks that include international investment banks, economic strategists, business media, think tanks, international organizations and foreign policy-makers; and b) governmental knowledging technologies of power, such as identification, investability and agency, were deployed to privilege and naturalize the BRIC economies as objects of 'hope'/'strength' relevant for the imagined recovery of the global political economy.

This imaginary is negotiated and appropriated diversely. Within the BRIC discourses, China is singled out as unique and, within the Sinophone world, it is recontextualized as the four golden brick countries' that symbolizes China 'strength' and sign of 'greatness-at-last' through its capacity to 'protect 8\% GDP growth rate'. With the onset of the 2007 financial crisis, China continued its investment-led strategy by marshalling a vast economic stimulus package which has intensified some deep-rooted tensions within its national-local political economy. On the national-local level, the stimulus package signifies a central-government 'green light' for bringing forward 'pet projects' of regional and local governments. Given that these authorities are supposed to provide 70 percent of the fund, land is increasingly used to leverage loans and to raise revenue. Land sales and property development become important investment and speculative activities with underlying costs such as forced displacement from land, state terror, dispossession of the already vulnerable (for example, migrant children) and increasing inequality. These growing social tensions and unevenness characterize, in part, the 'dark side' of the stimulus package that is too often narrated in the (trans)national arena in 'hope'/'strength' terms. The CPE approach aims to offer ideological critiques of these hegemonic constructions as well as to highlight some local subaltern social sites (such as slum schools), everyday resistance (for example, 'Blood Map) and peasant riots that are often neglected and glossed over in globalized mainstream discourses and practices of understanding the materialities of BRIC constructions at national-local level. 
On the global level, some of the worries about the validity of the BRIC imaginary became stronger after 2010, prompting an initially gradual and then accelerating retreat in BRIC portfolio investments. Indeed, in 2013-14, the anticipation and then the first steps in tapering US quantitative easing and indications of US and European recovery have unsettled investors and governments in the BRIC economies and other emerging markets. There were panics and selling of South African rand, Indian rupee and Brazilian real. For example, the Brazilian real devalued by $20 \%$ coupled with inflation and social unrest in August 2013. Lord coined the term 'Fragile Five' (Brazil, Indonesia, India, Turkey and South Africa) in August 2013 to denote their vulnerabilities. Asslund of the Peterson Institute for International Economics even announced that 'the BRICS party is over' (2013). O'Neill himself was reported in saying that ' $/ f$ / were to change it, I would just leave the " $C$ '" (Magalhaes 2013). He even started to promote new acronyms called MINT (Mexico, Indonesia, Nigeria and Turkey), CIVETS (Colombia, Indonesia, Vietnam, Egypt, Turkey and South Africa), and MIST (Mexico, Indonesia, South Korea and Turkey) as the transnational imaginaries. The MINT, CIVETS and MIST were seen as the 'new BRIC on the block (Yuk 2013). It is beyond the remit of this paper to examine these new acronyms but it would be most interesting to examine these cases from Turkey's perspective. On this, a CPE approach can shed light on the importance of imaginaries as well as the underlying extradiscursive context to which they relate. The BRIC imaginary captured for a time key trends in the world economy and even helped to create the potential that it identified., not only economically but also politically. But continuing global trends, including the financial and economic repercussions of crisis-management policies in the advanced economies, have increasingly, as some anticipated, turned the BRIC imaginary sour and prompted the search for new narrations of hope and strength. Turkey lies at the heart of these new financial imaginaries.

\section{Notes}

${ }^{1}$ Sum (2004) elaborates this approach in outlining six discursive-material moments involved in the remaking of social relations; see also Sum and J essop (2013).

${ }^{2}$ For details of these products, search BRIC at http://www.goldmansachs.com/our-thinking/archive, accessed 8 February 2014.

${ }^{3}$ South Africa joined the BRIC summit in 2011 at the invitation of China.

${ }^{4}$ In the G20 Pittsburgh Meeting (September 2009), the discussion of I MF governance reform was blocked by European governments - notably France and the UK - because of worries about losing influence at the IMF. On $25^{\text {th }}$ April 2010, China's voting power in the World Bank increased from 2.78 to 4.42 per cent.

${ }^{5}$ The fundamental differences among the BRIC include diverse political systems, and dissimilar views on key policy issues such as free trade and energy pricing.

${ }^{6}$ For details of the 'Blood Map', see 'Elusive 'blood map' founder speaks out', http://observers. france24.com/content/20101119-china-evictions-violence-blood-map-googlefounder-speaks-out, accessed 8 February 2014.

${ }^{7}$ The Hukou system refers to residential requirements in China Migrants, who do not belong to the Hukou system in the urban area, are not entitled to public housing, education for their children or local pension and health care benefits. This system is changing but it still favours the educated migrant communities.

8 'Editorial calls for abolition of hukou system', South china Morning Post, 2 March 2010, http://www.scmp.com/article/707381/editorial-calls-abolition-hukou-system, accessed on 8 February 2014. 


\section{References}

Åslund, A. (2013) Now the Brics Party is Over, They must Wind Down the State's Role, Financial Times, 27 August. Available at http://www.ft.com/cms/s/0/0147b43c-040b11e3-8aab-00144feab7de. html\#axzz2slbmgNbH, accessed 08 February 2014.

Buchanan, M. (2009) Decoupling is Happening for Real, 10 J uly 2009 http://www.chartwelletfadvisor. com/etf-news/etters/vol06-iss096.pdf, accessed on 21 February 2013.

Business Week (2010) China Construction Bank 2009 Profit Up 15 Percent, 28 March, http://www.businessweek.com/ap/financialnews/D9EO1OQ00.htm, accessed on 08 February 2014.

China Daily (2010) China's Land Sales Revenue Close to \$ 233 bln in 2009, 2 February http://www.chinadaily.com.cn/china/2010-02/02/content_9417378. htm, accessed on 1 March 2013.

Cruikshank, B. (1999) The Will to Empower, Ithaca: Cornell University Press.

Drezner, Daniel J . (2009) BRIC-a-brac, http://drezner.foreignpolicy.com/posts/2009/06/17/bric-a-brac, accessed on 08 February 2014.

Dean, M. (1999) Governmentality: Power and Rule in Modern Society. Thousand Oaks: Sage. Evans-Pritchard, A. (2011) Goldman Sachs Shuns the BRIC for Wall Street, http://www.telegraph.co.uk/finance/economics/8265175/Goldman-Sachs-shuns-theBRICs-for-Wall-Street.html, accessed 08 February 2014.

FlorCruz, J. (2009) Will the China Property Bubble Pop?, http://www.cnn.com/2009/BUSINESS/12/30/china. property. bubble/index.html, accessed 08 February 2014.

Goldman Sachs (2010) Idea Website on BRIC, http://www2.goldmansachs.com/ideas/brics/index.html, accessed on 08 February 2014.

Hsing, Y-T. (2010) The Great Urban Transformation: Politics of Land and Property in China. Oxford: Oxford University Press.

Investment U (2009) Profit from the 'New Decoupling', http://www. investmentu.com/IUEL/2009/J uly/decoupling-emerging-markets.html, accessed 08 February 2014.

Kelly, B. (2009) Brazil, Russia, India and China (the BRICS) Throw Down the Gauntlet of the International Monetary System, 28 J une, http://www. eastasiaforum.org/2009/06/28/brazil-russia-india-and-china-the-bricsthrow-down-the-gauntlet-on-monetary-system-reform/, accessed on 8 February 2014. 
Li, R. (2010) Schools' demise forces migrant children home. South China Morning Post, 03 February, available at $h t t p: / / w w w . s c m p . c o m / a r t i c l e / 705325 /$ schools-demise-forcesmigrant-children-home, accessed on 08 February 2014.

Lord, J. (2013) EM Currencies: Fragile Five, Morgan Stanley Research, 1 August, p.15, http://www.morganstanleyfa.com/ public/projectfiles/dce4d168-15f9-4245-9605e37e2caf114c. pdf, accessed on 8 February 2014.

Lordabett.com (2009) Why Decoupling Should Benefit International Investors, https://www. Iordabbett.com/articles/wp_why_decoupling_should.pdf, accessed on 3 March 2010.

Magalhaes, L. (2013) China Only BRIC Country Currently Worthy of the Title - O'Neill, Wall Street Journal, 23 August, http://blogs. wsj.com/moneybeat/2013/08/23/china-onlybric-country-currently-worthy-of-the-title-oneill/, accessed 08 February 2014.

Marinis, A. (2008) BRIC Consumers Can't Hold Off World Recession, Livemint.com, http://www.livemint.com/2008/12/18211911/Bric-consumers-can8217t-hol.html, accessed on 08 February 2014.

Mellor, W. and Lim, L-M. (2008) BRIC Shoppers will 'Rescue World', Goldman Sachs Says, http://www.bloomberg.com/apps/news?pid=newsarchive\&sid=a3aTPjYcw8a8, accessed 8 February 2014.

Miller, P. and Rose, N. (2008) Governing the Present, Cambridge: Polity.

Naughton, B. (2009) Understanding Chinese Stimulus Package, Chinese Leadership Monitor No. 28, Spring, http://www. hoover.org/publications/clm/issues/44613157.htm/, accessed on 08 February 2014.

O'Neill, J. (2009) The New Shopping Superpower, http://www.newsweek.com/2009/03/20/the-new-shopping-superpower.html, accessed on 8 February 2014.

Powell, B. (2010) China's Property: Bubble, Bubble, Toil and Trouble, Time, 22 March, http://www.time.com/time/magazine/article/0,9171,1971284,00.htm/, accessed on 8 February 2014.

Renard, T. (2009) A BRIC in the World: Emerging Powers, Europe, and the Coming Order, Royal Institute for International Relations, Egmont Paper 31, Brussels: Academia Press.

Rossi, V. (2008) Synchronized Dive into Recession: Focus on Damage Limitation, International Economic Programme, Oct 2008, IEP BP 08/04, http://www. chathamhouse.org/sites/default/files/public/Research/International\%20E conomics/bp1008recession.pdf, on 8 February 2014.

Sanderson, H. (2008) China Wants More Say in Global Financial Bodies, USA Today, 29 October, http://www. usatoday.com/money/economy/2008-10-292068576087 _.htm, accessed on 08 February 2014. 
Schiff, P. (2008) Little Book of Bull Moves in Bear Markets. Chichester: Wiley.

Scher, R. (2009) From BRIC to BIC ... or Even to IC??, New York: Foreign Policy Association, http://risingpowers. foreignpolicyblogs. com/2009/06/08/from-bric-tobic\%E2\%80\%A6or-even-ic/, accessed 8 February 2014.

Schmidt, G. (2010) Erasing our Innovation Deficit, http://www.washingtonpost.com/wpdyn/content/article/2010/02/09/AR2010020901191. htm/, accessed 08 February 2014.

Shinnick, R. (2008) Decoupling Thesis Intact, Seeking Alpha, 10 February 2008, http://seekingalpha.com/article/63886-decoupling-thesis-intact, accessed on 8 February 2014.

Smith, C. (2010) Global Economy's Next Threat: China's Real Estate Bubble, http://www. dailyfinance.com/story/global-economys-next-threat-chinas-real-estatebubble/19302329/\#, accessed 8 February 2014.

Sum, N-L. (2004) Discourses, material power and (counter-)hegemony, http://www.lancaster.ac.uk/cperc/docs/Sum\%20CPERC\%20Working\%20Paper\%2020 12-01.pdf, accessed on 8 February 2014.

Sum, N-L. (2011) Financial Crisis, Land-Induced Financialization and the Subalterns in China, in C. Scherrer (ed.) Social China. Berlin: Springer-Verlag, 199-208.

Sum, N-L. and Jessop, B. (2013) Towards a Cultural Political Economy: Putting Culture in its Place in Political Economy. Cheltenham: Edward Elgar.

Tasker, P. (2010) Beware the lure of GDP when seeking stocks in Brics, http://www.ft.com/cms/s/0/18f2c282-ff1b-11de-a677-00144feab49a.htm/, accessed on 8 February 2014.

Tett, G. (2010) The Story of the Brics, http://www.ft.com/cms/s/2/112ca932-00ab-11dfae8d-00144feabdco. $h t m l$, accessed on 08 February 2014.

Tong, S. and Zhang, Y. (2009) China's Responses to the Economic Crisis, EAl Background Brief No. 438, National Singapore University, http://www. eai.nus.edu.sg/BB438.pdf, accessed on 8 February 2014.

Wilson, D. and Purushothaman, R. (2003) Dreaming with the BRICs: the Path to 2050, Goldman Sachs Global Economic Research Website, Global Economic Paper No. 99, http://www.goldmansachs.com/japan/ideas/brics/book/99-dreaming.pdf, accessed on 8 February 2014.

Window of China (2009) China Updates Details of Stimulus Fund, 21 May, http://news.xinhuanet.com/english/2009-05/21/content_11415559. htm, accessed on 8 February 2014.

Yuk, P. K. (2013) MINT: the New BRIC on the Block?, http://blogs. ft.com/beyondbrics/2013/11/14/mint-the-new-bric-on-the-block/, accessed 14 Nov 2014. 
A Cultural Political Economy of Financial Imaginaries: the (Re-)Making of 'BRIC' and the Case of China

Zhang, M. (2010) CBRC beefs up measures, Shanghai Daily, 25 February, http://www.shanghaidaily.com/Business/finance/CBRC-beefs-upmeasures/shdaily.shtml, accessed 8 February 2014. 